\title{
Badiou's Biopolitics : The Human Animal and The Body of Truth
}

\section{Prozorov, Sergei}

2014-12-09

Prozorov , S 2014 , ' Badiou's Biopolitics : The Human Animal and The Body of Truth ' ,

Environment and Planning D: Society and Space , vol. 32 , no. 6 , pp. 951-967 . https://doi.org/10.1068/d14089p

http://hdl.handle.net/10138/233449

https://doi.org/10.1068/d14089p

acceptedVersion

Downloaded from Helda, University of Helsinki institutional repository.

This is an electronic reprint of the original article.

This reprint may differ from the original in pagination and typographic detail.

Please cite the original version. 
This is a post-peer-review, pre-copyedit version of an article published in Environment and Planning D: Society and Space, vol. 32, issue 6. The final authenticated version is available online at: https://doi.org/10.1068/d14089p.

\author{
Sergei Prozorov
}

\title{
Badiou's Biopolitics: The Human Animal and the Body of Truth
}

\section{Introduction}

Alain Badiou is known to be a principled opponent of biopolitics. ${ }^{1}$ His political writings since the 1982 Theory of the Subject onwards have featured passionate polemics against the reduction of politics, which Badiou ranks among the four 'truth procedures' along with art, science and love, to the management of the bare existence of human beings. ${ }^{2}$ For Badiou biopolitics is one of the manifestations of contemporary nihilism, a time devoid of truths. To the ethico-political discourses that valorize the 'human animal' and assign the supreme value to its life Badiou has famously opposed his version of a militant politics of fidelity to the event that ruptures the existing forms of life in any given world. This praxis, whose variations Badiou finds throughout human history from the slave rebellions of the Antiquity through the peasant wars of the Reformation to the revolutionary war in China, produces in the world what Badiou calls its truth, which transcends the particular features of worldly beings and transforms the world in its entirety on the basis of the idea of equality.

Badiou is certainly not alone in being critical of the phenomena usually placed under the rubric of biopolitics - most of the scholars of biopolitics have also been less than optimistic with respect to the transformations in the government of life they have analyzed. ${ }^{3}$ Where Badiou differs from these authors is that while these authors nonetheless approach biopolitics as the inescapable tendency of late-modern politics that must be reckoned with in the hope of being transformed, he quite unapologetically abandons the very problematic of biopolitics in favour of the politics of militant activism that sets the concerns of 'mere life' aside in favour of the constitution of a new, different, true life.

In this article we shall argue that it is precisely this move of setting mere life aside that makes problematic Badiou's claim to abandon or overcome the biopolitical paradigm. Our argument unfolds in three steps. In the first section we shall reconstruct Badiou's account of the contemporary biopolitical regime that he terms 'democratic materialism' and his alternative politics of subjective incorporation into the 'body of truth'. In the second section we shall demonstrate that Badiou's 'anti-biopolitics' replicates the basic logic of biopolitics as formulated by Giorgio Agamben: the inclusive exclusion of bare life, which figures in the political order of bios solely in the mode of being set aside to the margins. Badiou's 'body of truth' is dependent on the incorporation of the actual bodies of human beings in order to sustain the truth procedure, even as it simultaneously expects them to set the concerns and 
interests of these bodies aside to attain a new, better or truer life. Yet, the introduction of ideas of how life is to be governed or transformed does not do anything to change the basic setting of the capture of life as the object of power - if anything, by seeking to transform this life into something new it manifests this capture ever more starkly. Thus, our first conclusion is that rather than exemplify a successful overcoming of biopolitics, Badiou's politics of truth ends up a paradigmatic expression of the biopolitical logic.

Yet, such an interpretation remains insufficient insofar as it does not pay attention to the content of Badiou's truths and the process of their generation, which make his version of biopolitics genuinely different from the more familiar forms of biopolitics. In the third section we shall therefore trace the unfolding of the truth procedure in Being and Event in order to demonstrate how the emergence of Badiou's truth in the fidelity to the undecidable event deprives it of all positive, 'encyclopedic' content and makes it an generic subset of the situation, whose essence is indiscernible but whose existence is assured. The truth of the situation or world is contained in their very being as inconsistent multiplicities prior to any internal ordering and structuration. This thesis recalls Agamben's definition of affirmative biopolitics as the constitution of a bios that is only its own zoe, in which the logic of inclusive exclusion becomes inoperative, because bios and zoe are ultimately indistinct. We shall demonstrate that despite their many differences, Agamben and Badiou actually espouse a very similar onto-political orientation, in which generic, indiscernible 'whatever being' becomes the basis for undermining and transforming worlds, whose positive orders have no ontological foundation. We therefore conclude that Badiou is neither an opponent nor a proponent of biopolitics as we know it, but rather presents a version of 'affirmative biopolitics', which opposes to the biopolitical negation of bare life an emancipatory politics derived from life itself.

Bodies and Truths: Badiou on Democratic Materialism

Badiou begins his Logics of Worlds with a striking summation of the 'natural belief' or spontaneous ideology of late-modern Western societies: 'There are only bodies and languages. ${ }^{4}$ Badiou terms this ideology democratic materialism. It is a materialism because '[the] contemporary world recognizes the objective existence of bodies alone. Who does not de facto subscribe to the dogma of our finitude, of our carnal exposition to enjoyment, suffering and death? ${ }^{\prime 5}$ If there are only bodies, if existence itself is only conceivable as biological life, humanity is reduced to an 'overstretched version of animality': "Human rights' are the same as the rights of the living. The humanist protection of all living bodies: this is the norm of contemporary materialism. Today, this norm has a scientific name: 'bioethics', whose progressive reverse borrows its name from Foucault: 'biopolitics'. Our materialism is therefore a materialism of life. It is a bio-materialism. ${ }^{6}$

Why is this bio-materialism democratic? This is because it recognizes all the languages that these bodies use as formally or juridically equal: '[The] assimilation of humanity to animality culminates in the identification of the human animal with the diversity of its subspecies and the democratic rights that inhere in this diversity. Communities and cultures, colours and pigments, religions and clergies, uses and customs: everything and everyone deserves to be 
recognized and protected by the law. ${ }^{7}$ Everyone, that is, except those who refuse to recognize the universal equality of particular languages and wish to regulate other languages and bodies. All that democratic materialism does not tolerate is 'totalitarianism', understood as the desire to elevate the status of some bodies or some languages to the dominant status. Instead, bodies and languages are set free to interact and compete in the space regulated only by the general equivalent that assumes the form of money. Democratic materialism is thus the latest name Badiou gives to the spontaneous ideology of contemporary capitalism.

This description of democratic materialism echoes Badiou's earlier polemic in Ethics against the ethics of human rights and responsibility to otherness, whose ontological precondition is precisely the world composed solely of bodies and languages, whose existence must be protected against violence, respectively physical and cultural. ${ }^{8}$ At the heart of Badiou's critique of this ethics is, firstly, its reduction of the human being to the 'living animal', a 'biped without feathers whose charms are not obvious'. ${ }^{9}$ While, as we shall see below, for Badiou the human is defined by its capacity for transcending its animality and becoming the subject of the immortal truth (super-human), the ethics of human rights reduces the human to a potential victim of violence or oppression that destroys its very humanity, a sub-human. While avowedly concerned with the life and happiness of human being, this ethics remains perversely fascinated by death since it is the only thing that can really happen to someone'. ${ }^{10}$

Secondly, Badiou opposes the valorization of the differences between speaking bodies, be they cultural, national or religious. His main target here is the Levinasian-Derridean ethics of responsibility to otherness, which he sees as oscillating between an ultimately religious discourse of piety before the wholly Other and a hypocritical 'sociological' discourse, in which the empirical other is celebrated as long as it respects the differences of others, i.e. enacts the identity of tolerance, multiculturalism, etc. 'Ethical ideology, detached from the religious teachings which at least conferred upon it the fullness of a 'revealed' identity, is simply the final imperative of a conquering civilization: 'Become like me and I will respect your difference. ${ }^{11}$ Against these two equally unpalatable versions of the ethics of otherness, Badiou argues that difference must be deposed as an ethical principle and rethought as an elementary ontological fact:

[Infinite] alterity is quite simply what is. Any experience at all is the infinite deployment of infinite differences. But what we must recognize is that these differences hold no interest for thought, that they amount to nothing more than the infinite and self-evident multiplicity of humankind, as obvious in the difference between me and my cousin from Lyon as it is between the Shiite 'community' of Iraq and the fat cowboys of Texas. ${ }^{12}$

While the differences between bodies and languages are in themselves ethically indifferent, the true beneficiary of the ethics of alterity is the space of general equivalence constituted between them: 'Capital demands a permanent creation of subjective and territorial identities in order for its principle of movement to homogenize its space of action; identities, moreover, that never demand anything but the right to be exposed in the same way as others to the uniform prerogatives of the market. The capitalist logic of the general 
equivalent and the identitarian and cultural logic of communities or minorities form an articulated whole.'13

Let us now consider the way Badiou articulates his alternative to democratic-materialist biopolitics. After briefly toying with the idea of naming his approach 'aristocratic idealism' ${ }^{14}$, Badiou settles on the term 'materialist dialectic', which introduces into the dualistic axiomatic of bodies and languages a third term in the manner of the exception: 'there are only bodies and language, except that there are truths': 'There is no doubt whatsoever concerning the existence of truths which are not bodies, languages or combinations of the two. These truths are incorporeal bodies, languages devoid of meaning, generic infinities, unconditional supplements. ${ }^{15}$ Badiou does not disagree with the fact that what there is are, for the most part, bodies and languages, manifested to us in their difference that is of no political or philosophical consequence. Yet, that's not all there is in the world and what is politically relevant is precisely that which transcends bodies, languages and the market in which they are rendered equivalent. Truths occur as an exception to what is - they are neither bodily nor linguistic, even though, as we shall see, their unfolding in the world is dependent on both.

For Badiou, truths are 'wholly singular bodies (post-evental bodies) which compose the multiple materiality wherein special formalisms (subjective formalisms) are set out.' ${ }^{16}$ Like everything else in the world, truths are bodies, yet they are nonetheless bodies of a different and somewhat paradoxical kind: eternal even though produced in empirical time, trans-linguistic even though inscribed in a particular language, infinite even if upheld by finite beings. Truth is a body that has been marked by an event erupting in the world, whose consequences are 'operated' by the subject. The theorization of this new body takes up most of the six hundred pages of Logics, where Badiou first develops an 'objective phenomenology' of worlds and supplements it with an account of the appearance in these worlds of 'transworldly' post-evental truths affirmed by faithful subjects.

In technical terms, the body of truth is constituted by the process of incorporation of the elements of the site, where the event erupts, into the traces of its eruption ('the evental present'). This body will then be able to 'treat' various points of the transcendental order of the world, deciding for or against the persistence of the truth procedure. ${ }^{17}$ It is important to stress that it is the formation of this new body and not the mere eruption of the event that makes the truth procedure possible: if no elements of the site incorporate themselves to the evental present, the world in question will remain 'inconsequential' even if the event did take place therein. ${ }^{18}$ In contrast, the constitution of the body of truth generates the faithful subject that is able to produce the positive consequences of the event in its world. Thus, whereas democratic materialism correlates 'life and individuals', his materialist dialectics correlates 'truth and subjects'. ${ }^{19}$ This statement clearly demonstrates Badiou's eagerness to take distance from biopolitics: while democratic materialism can only envision politics in terms of the regulation of the actualization by bodies of their vital resources, for materialist dialectic politics presupposes the appearance of a new body of truth, and of the subject (individual or collective) that is constituted by incorporation into this body.

Can a politics that operates with the categories of truth and subject dispense with the notion of life? Badiou recognizes that 'life' has become the central 'signifier of democratic materialism' and even subsumes Foucault's philosophy, that of biopolitics included, under 
this signifier as a 'linguistic anthropology', a philosophy for which there is also nothing but bodies and languages. ${ }^{20}$ He nonetheless insists that the word may still be salvaged for philosophy in the manner that evades the doxa of democratic materialism by producing a 'new definition of bodies, understood as bodies of truth, or subjectivizable bodies'. ${ }^{21} \mathrm{He}$ then proceeds to redefine life as 'participation, point by point, in the organization of a new body, in which a faithful subjective formalism comes to take root'. ${ }^{22}$ In the final chapter of Logics entitled 'What is it to live?' the difference between the life of democratic materialism and Badiou's 'true life' is accentuated most starkly: "To live' obviously not in the sense of democratic materialism (persevering in the free virtualities of the body) but rather in the sense of Aristotle's enigmatic formula: 'to live as an Immortal'. ${ }^{23}$ 'True life' is not determined by the world and its ways, but rather by what 'inappears' in the world, i.e. the event whose occurrence is immediately evanescent yet leaves traces in the form of the maximized intensity of existence of those elements formerly consigned to the status of the 'inexistent' of the world. To live truly is to incorporate oneself in this evental present, to actively participate in the unfolding of the consequences of the event, to be a faithful subject of the new body of truth. There are of course other possibilities. The reactive subjective formalism seeks to erase every trace of the event, restoring the ways of the world as if nothing had taken place. The obscure formalism seeks to destroy the post-evental body of truth and replace it with a phantasmatic transcendent body, in which there is no division and no place for an event. ${ }^{24}$

[Life] is a subjective category. A body is the materiality that life requires, but the becoming of the present depends on the disposition of this body in a subjective formalism. To live is thus an incorporation into the present under the faithful form of a subject. If the incorporation is dominated by the reactive form, one will not speak of life but of mere conservation. It is a question of protecting oneself from the consequences of a birth, of not relaunching existence beyond itself. If incorporation is dominated by the obscure formalism, one will instead speak of mortification. ${ }^{25}$

While the reactive subject exemplifies the conservative ('ill-named') life drive and the obscure subject exemplifies the 'death instinct', life in the body of truth is 'what gets the better of the drives' (ibid.: 509). ${ }^{26}$ This life takes exception from the order of bodies and languages and thereby introduces into the world the dimension of the Idea. Badiou's difference from democratic materialism is particularly vivid with regard to the Idea. In the world of only bodies and languages any reference to an Idea, particularly when capitalized, is suspect as the 'totalitarian' attempt to absolutize one's language as the one all speaking bodies must abide by. Yet, in Badiou's politics of truth the Idea is precisely not a language (even if it might rely on linguistic forms), but the experience of subjectivation transcending the bodily-linguistic resources of the world. One's submission to the Idea is then not the experience of servitude but rather of authentic freedom that, depending on the type of the truth in question, takes the form of joy (science), happiness (love), pleasure (art) or enthusiasm (politics). ${ }^{27}$

Since it does not recognize the exceptional existence of truths, the biopolitics of democratic materialism remains hostile to the Idea as such, proclaiming 'the end of ideologies' as the good news, making it possible for speaking bodies to finally 'live without Idea'. While it is 
ostensibly a humanist ideology, democratic materialism only affirms that within the human which is reducible to the animal and fears that 'inhuman' capacity for truths that, for Badiou, makes the human in the first place: 'if one fails to recognize the effects of those traces in which the inhuman commands humanity to exceed its being-there, it will be necessary, in order to maintain a purely animalistic, pragmatic notion of the human species, to annihilate both these traces and their infinite consequences. The democratic materialist is a fearsome and intolerant enemy of every human - which is to say inhuman - life worthy of the name. ${ }^{28}$

And yet, there is a perpetual possibility for human beings to avoid both conservation and mortification and embark on a true life. This is because for Badiou the human being traverses numerous worlds throughout its existence. There must therefore be some worlds in which an event, the first condition of the truth, has happened or is happening, and which therefore offer the possibility of setting aside one's mere life for a new life in the body of truth.

Incessantly in some accessible world something happens. Several times in its brief existence, every human animal is granted the chance to incorporate itself into the subjective present of a truth. The grace of living for an Idea, that is living as such, is accorded to everyone and for several types of procedure. The infinite of worlds is what saves us from every finite dis-grace. Finitude, the constant harping on of our mortal being, in brief, the fear of death as our only passion - these are the bitter ingredients of democratic materialism. We overcome all this when we seize hold of the discontinuous variety of worlds and the interlacing of objects under the constantly variable regimes of their appearances. We are open to the infinity of worlds. To live is possible. Therefore, to (re)commence to live is the only thing that matters. ${ }^{29}$

This is what a true life is: a life constituted by the participation in the post-evental body of truth, whereby the mortal animal 'overcomes' the finitude of its mere bodily existence and becomes a subject of the immortal truth. While the valorization of life in the biopolitics of democratic materialism produces only its negative obverse of the preoccupation with finitude and the fear of death, Badiou's politics of truth achieves a true life of maximal existential intensity by setting aside all concerns with one's finitude, subordinating one's mere animality (sub-humanity) for the process of the construction of the super-human bodies of truth. Biopolitics as politics of mere life is overcome by the politics of truth that alone makes it possible to truly live.

\section{The Body of Truth and the Return of Biopolitics}

While Badiou's politics of truth has been critically addressed from a variety of perspectives, ${ }^{30}$ what interests us is its presentation as an alternative to biopolitics. This presentation appears questionable from the outset, insofar as Badiou is neither willing nor able to abandon the very terms that define the biopolitical regime that he criticizes. Firstly, the 'intra-worldly' advance of the truth procedure requires material support in the living body, without which it remains abstract and impotent. The transworldly body of truth is 
ultimately composed of the worldly physical bodies, even as it aspires to transcend their particularity: 'The Immortal exists only in and by the mortal animal.' ${ }^{31}$ We may speak either of the incarnation of the truth in the body of the human animal or the incorporation of this animal into a new, subjective 'body of truth' - either way, the truth procedure cannot proceed without latching on to the bodies it desires to transcend.

Secondly, the result of incorporation into the body of truth is nothing other than life and, moreover, 'living as such'. ${ }^{32}$ The setting aside of the mere life of the subhuman animal leads to a true life, which 'gets the better' of bio-psychological drives and makes it possible to live 'as an Immortal'. There is certainly a difference between the two notions of life at work here, the sub- and the super-human ones, but life itself remains the sole horizon of politics. In fact, it is precisely the move from one notion of life to another, from one body to another, that defines biopolitics in Giorgio Agamben's famous interpretation. For Agamben biopolitics begins with the 'inclusive exclusion' of zoe (unqualified life that we share with both animals and gods) into bios (a qualified form of life in the polis). ${ }^{33}$ The constitution of bios as the political form of life presupposes the entry of zoe into this realm in the marginalized, subordinated or suppressed position: it is included in the polis, but solely in the mode of its exclusion from it, as a negative foundation, 'as if politics were the place in which life had to transform itself into good life and in which what had to be politicized were always already bare life'. ${ }^{34}$ Just as in his earlier Language and Death Agamben traced the logic of negative foundation at the heart of language, ${ }^{35}$ whereby the natural voice of the living being is negated for signifying discourse to become possible, in Homo Sacer he demonstrates how every qualified form of political existence is founded on the inclusive exclusion of zoe that figures in the polis in the destitute and degraded form of bare life. ${ }^{36}$

[The] question 'in what way does the living being have language?' corresponds exactly to the question 'In what way does bare life dwell in the polis?' The living being has logos by taking away and conserving its own voice in it, even as it dwells in the polis by letting its own bare life be excluded, as an exception, within it. There is politics because man is the living being who, in language, separates and opposes himself to his own bare life and, at the same time, maintains himself in relation to that bare life in an inclusive exclusion. ${ }^{37}$

It is easy to observe the parallels between this logic and the constitution of Badiou's 'body of truth'. As Agamben himself argued, '[Badiou] still conceives of the subject on the basis of a contingent encounter with truth, leaving aside the living being as the 'animal of the human species' as a mere support for this encounter.' 38 Incorporating itself into the evental present, the human animal sets aside its animality or zoe in order to constitute a new form of life (bios) in the body of truth. The true life of the superhuman subject is obtained by the isolation of the physical life of the subhuman 'mortal animal' as its material support. The finite body of the human animal that Badiou derisively dismisses as a charmless 'biped without feathers' is absolutely necessary for the new body of truth to be possible, yet in this new body it no longer plays an important role, its particular interests and desires set aside in favour of the universal content of the truths. Moreover, the human animal is not merely set aside but also ends up 'disciplined' for the purposes of the more effective unfolding of the truth procedure: 'I place heroism on the side of discipline, the only weapon both of the True and of peoples, against power and wealth, against the insignificance and the dissipation of 
the mind. But this discipline demands to be invented, as the coherence of a subjectivizable body. Then it can no longer be distinguished from our own desire to live.' ${ }^{39}$ Evidently, discipline cannot be distinguished from the expression of the desire to live only if by 'life' we mean, as Badiou does, the participation in the body of truth. Yet, this is only possible if the mere life of the speaking body is set aside to the margins of the new body, into which it is nonetheless included as a necessary material support.

Yet, what about the democratic materialism that Badiou opposes? Isn't the latter the exemplary form of biopolitics, taking as its sole object the mere finite existence of speaking bodies? This is certainly true, yet only insofar as Badiou's formula is completed. The statement 'there are only bodies and languages' does not in itself authorize any biopolitics (or any other kind of politics for that matter). It is a strictly ontological claim that is politically indifferent: there is no reason why these bodies and languages should be privileged objects of politics, its material supports or serve any other function. In order to make this formula biopolitical we must add to it the specification of the form of life (bios) that these bodies are to be inclusively excluded from or, in Badiou's lexicon, of the body of truth into which they should be negatively incorporated: there are only bodies and languages except that there is the truth, into whose body they are incorporated. This specification is necessary even if the truth in question consists precisely in the valorization of speaking bodies as 'all there is'. In fact, this is precisely the mode of biopolitics that, in Agamben's argument, characterizes the late-modern condition, marked by the decline or 'bankruptcy' of the familiar forms of bios (liberalism, socialism, nationalism, etc.), which leaves bare life as the last legitimate object of political power: 'The only task that still seems to retain some seriousness is the assumption of the burden of biological life, that is, of the very animality of man. ${ }^{\prime 40}$ While this nihilistic biopolitics is possible and perhaps to some degree actual in contemporary Western societies, it only exemplifies the extreme case of the biopolitical logic and not its paradigm. To be against the nihilism of 'democratic materialism', as Badiou is, is not to oppose biopolitics as such. Politics becomes biopolitics when it captures zoe inside the bios that it constitutes, not when it ends up, for lack of other objects, applying itself to zoe exclusively. ${ }^{41}$

Moreover, Badiou's own presentation of democratic materialism gives us reason to doubt that the condition he describes is indeed reducible to a purely nihilistic management of the 'very animality of man', a life that is truly 'without Idea'. Let us recall Badiou's claim that the juridical equality of all bodies and languages functions as a regulative principle permitting the exclusion and even elimination of those bodies and languages that claim ascendancy over others in a quasi-totalitarian manner. ${ }^{42}$ Similarly, in Ethics Badiou asserts that the valorization of otherness tends to coexist with the fear of '[any] vigorously sustained difference. African customs are barbaric, Muslims are dreadful, the Chinese are totalitarian, and so on. This celebrated 'other' is acceptable only if he is a good other, which is to say, the same as us.' ${ }^{43}$ The existence of a 'halting point' to tolerance and multiculturalism, whereby the other's own tolerance becomes the condition of the tolerance of the other, clearly goes beyond the sheer ontological affirmation of there being only bodies and languages. Instead, 'tolerance' or 'multiculturalism' constitute precisely the form of life (bios) into which speaking bodies are incorporated as subjects of the truth that transcends bodies and languages and subjects them to a certain discipline and, if necessary, punishment. The logic of the inclusive exclusion of zoe into bios is thus clearly operative even in the forms of life, in which zoe and bios are almost indistinct. 
Thus, we cannot agree with Badiou's interpretation of democratic materialism in terms of a purely nihilistic injunction to live without Ideas. Any investigation of the spontaneous ideology of contemporary Western societies would easily point to the idea of freedom as the key component of the contemporary biopolitical rationality, in the name of which bodies and languages may be mobilized, disciplined and occasionally even annihilated. While it might be tempting to interpret contemporary neoliberalism in a quasi-Heideggerian manner as the nihilistic surrender to the nothingness of mere life, the evidence, e.g. from the studies of neoliberal governmentality, rather seems to point to its successful mobilization of all aspects of life in the service of the idea of freedom, specified in the economic terms of enterprise. ${ }^{44}$ Badiou certainly does not like this idea and would refuse to grant it the status of a truth, ${ }^{45}$ but it does not follow from this that the neoliberal idea of freedom is somehow reducible to the being of bodies and languages themselves.

We end up with an image that is rather different from the initial stark contrast between the biopolitics of democratic materialism and the politics of truth prescribed by materialist dialectics. Instead, both of these forms of politics exemplify the operation of the biopolitical logic of the inclusive exclusion of 'mere life' as the negative foundation of 'good life' (or 'true life'). This evidently does not invalidate Badiou's criticism of democratic materialism as a particular mode of biopolitics, but only his own attempt to transcend biopolitics by introducing new forms of bios to replace the 'truths' of tolerance, multiculturalism or entrepreneurialism, which he despises. There is no idea without a relation to life, hence Badiou's truth procedure remains biopolitical, but there is also no politics without ideas, hence democratic materialism is not without a certain 'truth-content' of its own. We may then conclude that attempts to overcome biopolitics that posit themselves as purely ideational, ideological or ideocratic, i.e. located on one side of the divide between life and idea, the vital and the symbolic, necessarily presuppose this divide and inevitably cross it in the search of the incarnation for the ideas that they affirm. What we find 'beyond' biopolitics is nothing but the potentiality, if not the aspiration, for becoming biopolitical.

\section{Generic Truths and Affirmative Biopolitics}

It would be possible to stop here, having demonstrated the belonging of Badiou's materialist-dialectical 'politics of truth' to the same biopolitical logic that he seeks to overcome. Yet, such a reading would be somewhat uncharitable, though not exactly wrong, since there remains an important qualitative difference between the truth that Badiou affirms and the ideology of democratic materialism. In the previous sections we have focused on Badiou's account of the formal constitution of the body of truth, which is indeed strictly homologous to the biopolitical 'inclusive exclusion' of bare life, practiced by democratic materialism and other familiar modes of biopolitics. Would things be any different if we now turned our attention to the content of Badiou's truths? Evidently, no variation in content would change the formal belonging of the politics of truth to the biopolitical logic. Yet, it is possible that it might produce a different kind of biopolitics.

The theme of affirmative biopolitics, which does not negate, exclude or dominate the life that it governs, has been addressed in various ways in contemporary Italian political 
theory. ${ }^{46}$ For our purposes, Agamben's formulation at the end of Homo Sacer would be most instructive: 'This biopolitical body that is bare life must itself instead be transformed into the site for the constitution and installation of a form of life that is wholly exhausted in bare life and a bios that is only its own zoe.' 47 Agamben's thesis is simultaneously enigmatic and rigorous. Indeed, if biopolitics includes zoe into bios in the destitute mode of bare life whose negation founds the political form of life, then the only possibility for biopolitics to refrain from this negation and begin to affirm life requires that bios and zoe become entirely indistinct. In this manner, life and its form would become entirely inseparable, bios being entirely contained in zoe, so that it is 'no longer possible to isolate anything like a bare life' $^{48}$

Agamben's solution becomes clearer with the help of the analogy he draws between bare life in biopolitics and pure being in philosophy:

[In] the syntagm 'bare life', 'bare' corresponds to the Greek haplos, the term by which first philosophy defines pure Being. And it may be that only if we are able to decipher the political meaning of pure Being will we be able to master the bare life that expresses our subjection to political power. ${ }^{49}$

On the basis of this analogy between bare life and pure being Agamben establishes the political equivalent of Heidegger's inversion of the relation between essence and existence in Being and Time. ${ }^{50}$ 'Today bios lies in zoe exactly as essence, in the Heideggerian definition of Dasein, lies in existence. ${ }^{51}$ If the essence of the human is unpresentable in terms of essential predicates ('what one is') but consists in the sheer facticity of its existence ('that one is'), then the sole form of bios proper to the human is indeed its own zoe, whose facticity is no longer the negated foundation of bios but rather its entire content, there being no other form, essence, task or identity imposed on it. What Agamben calls form-oflife, the hyphens emphasizing the integrity of life and its form, may then be understood as 'a being that is its own bare existence, [a] life that, being its own form, remains inseparable from it'..$^{52}$

We encounter this figure of an integral form-of-life in the most diverse contexts of Agamben's work: the 'coming community' of whatever singularities, ${ }^{53}$ the experimentum linguae that communicates the sheer existence of language and not its signified contents, ${ }^{54}$ the 'glorious body' that is nothing but the earthly body divested of its functions and open to a new use, ${ }^{55}$ Franciscan monastic life extraneous to every law and norm, ${ }^{56}$ etc. What unites all of these diverse figures is their subtraction from every particular predicate and their exposure in the bare facticity of their existence or 'being-thus'. A bios that is its own zoe is not some particular bios, some concrete form of life, but rather whatever bios, insofar as it is taken up solely in the aspect of its zoe. This obviously does not mean that this form of life is devoid of any real predicates but rather that these predicates are taken up all at once and thereby neutralized, no longer functioning as the conditions of belonging and exclusion: being-thus is 'neither this nor that, neither thus nor thus, but thus, as it is, with all its predicates (all its predicates is not a predicate). ${ }^{57}$

At first glance, this idea of a form of life wholly exhausted in bare life is very far from Badiou's line of thinking. As we have seen, Agamben has accused Badiou of sticking to a 
traditional biopolitical move of constituting the subject by inclusively excluding life as mere material support for truth. On his part, Badiou has been highly critical of Agamben's alleged valorization of bare life that is inherently devoid of truth.

[Agamben's] recurrent theme is being as weakness, its presentational poverty, power preserved from the glory of its act. Likewise, in politics, the hero is the one brought back to its pure being as a transitory living being, the one who may be killed without judgment, the homo sacer of the Romans, the Muselmann of the extermination camp. Agamben, this Franciscan of ontology, prefers, to the affirmative becoming of truths, the delicate, almost secret persistence of life, what remains to one who no longer has anything; this forever sacrificed 'bare life', both humble and essential, which conveys everything of which we - crushed by the crass commotion of powers - are capable of in terms of sense. ${ }^{58}$

This interpretation of Agamben is easily understandable from the activist-militant perspective of Badiou's politics of truth. Indeed, when it comes to politics the two authors tend to express themselves in rather different idioms. While Agamben does tend to focus on marginalized, oppressed and dehumanized figures, Badiou privileges heroic figures of grand politics (Spartacus, Muentzer, Mao). ${ }^{59}$ However, these differences may obscure a more subtle yet also more fundamental proximity between the two authors. Agamben and Badiou share the ontological approach to politics as the process of the affirmation of pure being against the radically contingent orders of worlds (Badiou) or apparatuses of government (Agamben), which have no ontological foundation. Just as Agamben's form-of-life is subtracted from every determination and only exposes its own existence, Badiou's truths lack any positive predicates and manifest nothing but the being of the 'situation' or 'world' as an inconsistent multiplicity. In the remainder of this section we shall revisit Badiou's account of the unfolding of the truth procedure in Being and Event and demonstrate that, for all the difference between Badiou's set-theoretical and Agamben's post-Heideggerian ontologies, the former author's body of truth is strictly correlative to the latter's form-oflife.

The event which initiates the truth procedure is defined by Badiou as composed of the elements of the evental site and itself. The evental site is a set that is absolutely singular, i.e., it belongs to the situation as an element but is not included into it in terms of its parts or subsets. Such a set is present in the situation as undecomposable, 'all of a piece', none of the elements that compose it being presented in the situation. For this reason it obviously cannot be counted in terms of its parts and thus remains without representation in the 'state of the situation', which operates by grouping the elements of the original set into subsets: 'Such a multiple is solely presented as the multiple-that-it-is. None of its terms are counted-for-one as such; only the multiple of these terms forms a one.' ${ }^{60}$ It is such absolutely singular sets that form sites of the event, without guaranteeing its actual eruption.

The other component of the event is, paradoxically and from a strictly ontological perspective impossibly, the event itself. Since the ontological axioms of set theory prohibit self-belonging, the very occurrence of the event remains invisible from the ontological perspective: 'Ontology has nothing to say about the event.' ${ }^{61}$ The belonging of the event to the situation must therefore be decided upon or 'wagered' in the procedure of intervention. 
This procedure 'names' the unpresented elements that belong to the evental site, which is 'illegal' from the ontological perspective, since it interrupts the representative structure of the state of the situation, which, as we have seen, cannot access the elements of this singular multiplicity. Thus, the intervention asserts ' $t$ t]he existence of representatives without any law of representation' ${ }^{62}$ It affirms that the event is being able to designate it as $a$ being. Thus, the effect of intervention is the assertion of the bare existence of an event, of its zoe rather than bios.

The more positive consequences of the event for the situation are established in the procedure that Badiou terms fidelity, which groups together the elements of the situation, whose existence is dependent on the event in question. The result of this grouping is a subset of the situation that is indiscernible within it, i.e. cannot be identified by the language of the state of the situation that Badiou terms 'encyclopedia'. ${ }^{63}$ It is this subset, which Badiou terms 'generic', that is granted the status of the truth of the situation, in distinction from the knowledge established in the 'encyclopaedic' language. This means that the truth cannot be grasped in terms of positive predicates that would make it possible for us to say that this or that aspect of the situation is true (or not). The generic subset 'contains a little bit of everything [but] only possesses the properties necessary to its existence as multiple in its material. It does not possess any particular, discerning, separative property. At base, its sole property is that of consisting as pure multiple, of being. Subtracted from language, it makes do with its being. ${ }^{64}$

If the truth makes do with its being without being discernible in language, if it does not possess any particular properties, its content must be exhausted in what pertains to the situation's very being prior to its internal structuration. Indeed, this is the only reason why this truth is deemed by Badiou to be universal, 'the truth of the entire situation, truth of the being of the situation'. ${ }^{65}$ If it were otherwise, if the truth manifested some particular novel content arising from the event, it could never have universal consequences for the situation but would merely produce an extraneous addition to it. Yet, as we have seen, the event does not produce any new content, but rather presents what was always in the situation to begin with but was not presented therein. To this presentation the event merely adds itself as the signature of its action that ensures that its own presentation remains presented. Thus, the event is not understood by Badiou as the advent of unprecedented novelty from out of the blue, but the emergence as new of what always belonged to the situation.

The same logic is at work in an even more accentuated manner in Logics of Worlds, where the consequence of the eruption of the event in a given world is the ascent of what was 'inexistent' in it (the element of the world that did not appear in the world) to maximal existence. ${ }^{66}$ This maximal existence is certainly 'new' from the perspective of the world's transcendental order but nothing new ontologically since the inexistent was in the world to begin with. Thus, the event and the post-evental truth procedure perform something like an 'ascent from appearance towards being' or the rise of being its elf to appearance. ${ }^{67}$ What the truth manifests is nothing more (and nothing less) than the being of the situation or world, which is that of inconsistent multiplicity, ${ }^{68}$ ordinarily concealed either by the structure of the situation (in the ontological terms of Being and Event) or the transcendental order of the world (in the phenomenological terms of Logics of Worlds). 
It is easy to see that the truth that brings to appearance the being of the situation itself is strictly identical to Agamben's form of life exhausted in bare life or a bios that is its own zoe. The 'body of truth', constituted in the procedure of fidelity, is a biopolitical body but, unlike other such bodies, it manages not to negate the living body of the human animal through its inclusive exclusion, only because what is 'excluded' from it (bare life as pure being) is exactly the same as what it is 'included' into (the truth as pure being). The body of truth is quite literally the same as the body of the living animal, yet it is not only that. Evidently, for Badiou's truth procedure of politics (as well as art, science and love) to make any difference in the world, it should produce some content other than what we began with. It is this 'added value' of the truth that apparently differentiates him from Agamben who is content with the politics of pure inoperativity. ${ }^{69}$ Yet, once again, the difference should not be overstated since for Badiou this content is both minimal and impossible to present as a positive political project. The sole content of the political truth procedure that he has recently elaborated in terms of the 'communist hypothesis'. ${ }^{70}$ 'Only a politics that can, in philosophy, be named an egalitarian politics entitles one to turn towards the eternal of the contemporary times in which this politics proceeds. ${ }^{71}$ As we have seen, equality was also a principle asserted by the democratic materialism and, indeed, also the only principle asserted by it. The difference between Badiou's politics of truth and the biopolitics he criticizes is thus entirely contained in the different concepts of equality that they utilize. While the juridical equality affirmed by democratic materialism is defined in programmatic terms as something to be attained in a political project (of recognition, protection, redistribution, etc.), Badiou's equality is rather 'immediately prescriptive', since it always already characterizes the being of every world, however unequally it is ordered in its appearance. ${ }^{72}$

[The] word 'equality' must be secured in the absence of any economic connotations (equality of objective conditions, of status, of opportunity). It subjective trenchancy must be restored: equality is something that opens onto a strict logic of the Same. Its advantage, then, lies in its abstraction. Equality neither presumes closure, nor qualifies the terms it embraces, nor prescribes a territory for its exercise. This word would not include within it the theme of the social, or of redistribution, and less still that of solidarity, of State solicitude for differences. Equality here is a purely philosophical name. It is unhitched from every programme. [It means] that no lone singularity can have an entitlement that would render it unequal to any other. This can also be said: the essence of a truth is generic, that is, is without any differential trait that would allow it to be placed in a hierarchy on the basis of a predicate. And again: equality signifies that, from the vantage point of politics, what is presented has no need of being interpreted. What presents itself must be received in the nondescript nature and the egalitarian anonymity of its presentation as such. ${ }^{73}$

It is easy to see that Badiou's notion of equality is simply a logical consequence of the genericity of the truth itself and not some extraneous principle or value: it arises out of the very character of the truth procedure as the ascent to appearance of the unpresented or inexistent elements in the form of the indiscernible subset, which does not possess any 
'differential trait' that would allow any unequal relation to be constituted. The indiscernible simply is without it being possible to specify, in the language of the situation, what it is: this is why it does not need to be and actually cannot be 'interpreted' but must be received in the sheer facticity of its existence, which is indeed characterized by 'nondescript nature' and 'egalitarian anonymity'. What this means is that Badiou's equality is never economic, legal, cultural or any other specific equality, but the equality of beings in their being, whatever these beings are in their worldly appearance, identity or role and, indeed, whatever world they happen to appear in. It is important to recall that the entire truth procedure begins with the event, which brings to presentation the formerly unpresented elements of its site, asserting the equality of everything that is in the situation against the unequal distribution of presentation in it. Similarly, in the Logics of Worlds, the event entails the rise of the inexistent of the world to maximal existence in it, overturning the internal order of the distribution of degrees of appearances within the world. Equality is not a positive principle defining a certain bios, yet neither is it a mere attribute of zoe: were it not for the event, the unpresented and the inexistent would have remained such. Equality as truth is rather the result of the raising of the ontological attributes of zoe to the status of bios, the affirmation of unqualified and indeterminate life as the sole content of political life.

Thus, Badiou's body of truth manifests nothing but the bodies of living animals that compose it plus their radical equality, which could never be inferred from their worldly existence as living animals, endowed with bodies and languages, but requires the traversal of the ontological dimension and the eruption of the event. Nonetheless, it is important to stress that the truth that ensues from this eruption is not an idea transcendent in relation to these bodies and languages but rather the result of the painstaking working through the ontological consequences of the fact of there being them and only them. Badiou's formula 'there are only bodies and languages, except that there are truths' may then be completed as 'there are only bodies and languages, except that there is also the truth of their equality'.

From this perspective, Badiou's critique of the biopolitics of democratic materialism remains fully valid but needs to be rearticulated. As we have argued, it is impossible to oppose a politics of truth to the biopolitics of 'life without Idea', firstly because the politics of truth ends up in need of the living body to sustain itself and, secondly, because the biopolitics of mere life turns out to be governed by ideas of freedom, tolerance or multiculturalism that, however flawed they might appear to Badiou(ans), are entirely irreducible to mere attributes of bare life. The problem with the biopolitics of democratic materialism is not that it is devoid of truths transcending the speaking body of the human animal. There is instead a whole market of such 'truths' in contemporary 'democratic-materialist' societies, from selfhelp to self-fulfilment, from tried and true religion to the most eccentric alternative spiritualities. The problem is rather that these 'truths' are too transcendent, utterly disconnected from the ontological equality of the bodies and languages and instead producing new hierarchies and divisions that have no ontological foundation whatsoever. To oppose this biopolitics one does not need to compete with it in inventing ever more transcendent truths but should rather focus on the one truth that is wholly immanent to whatever world it unfolds in, the truth that whatever is in the world is equal to whatever else there is in it. Affirmative biopolitics affirms neither a nihilistic life 'without idea' nor the domination of bare life by ideas of good life but the political consequences of the facticity of life as such. 
NOTES

${ }^{1}$ See Adrian Johnston, Prolegomena to any Future Materialism, Volume One: The Outcome of Contemporary French Philosophy (Chicago: Northwestern University Press, 2013), pp. 8991; Paul Livingston, The Politics of Logic: Badiou, Wittgenstein and the Consequences of Formalism (London: Routledge, 2012), 240; Tyson Lewis, 'Philosophy - Aesthetics Education: Reflections on Dance', The Journal of Aesthetic Education 41, no. 4 (2007): 53-66. 2 See Alain Badiou, Theory of the Subject (London: Continuum, 2009), 311.

3 See Michel Foucault, History of Sexuality. Volume One: An Introduction (Harmondsworth: Penguin, 1990); Giorgio Agamben, Homo Sacer: Sovereign Power and Bare Life (Stanford: Stanford University Press, 1998), Roberto Esposito, Bios: Biopolitics and Philosophy (Minneapolis: University of Minnesota Press, 2008).

${ }^{4}$ Badiou, Logics of Worlds (London: Continuum, 2009), 1.

5 Ibid., 2.

${ }^{6}$ Ibid.

7 Ibid.

8 Badiou, Ethics: An Essay on the Understanding of Evil (London: Verso, 2001), pp. 8-9.

9 Ibid., 12.

10 Ibid., 35.

11 Ibid., 25.

12 Ibid., pp.25-26.

13 Badiou, Saint Paul: The Foundation of Universalism (Stanford: Stanford University Press, 2001), 10.

${ }^{14}$ Badiou, Logics of Worlds, 3.

15 Ibid., 4.

16 Ibid., 9

17 See ibid., pp. 468-475, 483-491.

18 Ibid., 491.

19 Ibid., 34.

20 Ibid., 35.

21 Ibid.

$22 \mathrm{lbid}$

23 Ibid., 507

24 See ibid., pp. 54-61.

25 Ibid., pp. 508-509.

26 Ibid., 509.

27 Ibid., 511.

28 Ibid.

29 Ibid., 514.

30 See Bruno Bosteels, Badiou and Politics (Durham: Duke University Press, 2011); Peter Hallward, Badiou: A Subject to Truth (Minneapolis: The University of Minnesota Press, 2003).

31 Badiou, Ethics, 84.

32 Badiou, Logics of Worlds, 514. 
${ }^{33}$ Agamben, Homo Sacer, 6.

34 Ibid., 7.

${ }^{35}$ Agamben, Language and Death: The Place of Negativity (Minneapolis: The University of Minnesota Press, 1991), pp. 84-85.

36 See Leland de la Durantaye, Giorgio Agamben: A Critical Introduction (Stanford: Stanford University Press, 2009), pp. 202-205; Catherine Mills, The Philosophy of Agamben (Stocksfield: Acumen, 2008), 64.

37 Agamben, Homo Sacer, 8.

38 Agamben, Potentialities: Selected Essays in Philosophy (Stanford: Stanford University Press, 1999), 221.

39 Badiou, Logics of Worlds, 514.

${ }^{40}$ Agamben, The Open: Man and Animal (Stanford: Stanford University Press, 2004), pp. 7677.

${ }^{41}$ Agamben, Homo Sacer, 9.

42 Badiou, Logics of Worlds, pp. 2-3.

43 Badiou, Ethics, 24.

44 See e.g. Nikolas Rose, Powers of Freedom: Reframing Political Thought (Cambridge: Cambridge University Press, 1999), Barbara Cruikshank, The Will to Empower: Democratic Citizens and Other Subjects (Ithaca: Cornell University Press, 1999).

45 Badiou, Conditions (London: Continuum, 2008), 173.

46 See Esposito, Bios, pp. 146-193; Michael Hardt and Antonio Negri, Commonwealth (Cambridge: Harvard University Press, 2009), pp. 22-64.

47 Agamben, Homo Sacer, 188.

${ }^{48}$ Agamben, Means without End: Notes on Politics (Minneapolis: The University of Minnesota Press, 2000), 9.

${ }^{49}$ Agamben, Homo Sacer, 182.

50 Martin Heidegger, Being and Time (New York: Harper Collins, 1962), 67.

51 Agamben, Homo Sacer, 188.

$52 \mathrm{lbid}$.

53 Agamben, The Coming Community (Minneapolis: University of Minnesota Press, 1993).

${ }^{54}$ Agamben, Infancy and History: On the Destruction of Experience (London: Verso, 2007).

55 Agamben, Nudities (Stanford: Stanford University Press, 2010), pp. 91-103.

56 Agamben, The Highest Poverty: Monastic Rules and Form-of-Life (Stanford: Stanford University Press, 2013).

57 Agamben, The Coming Community, 93.

58 Badiou, Logics of Worlds, pp. 558-559.

59 Ibid., pp. 51-66, 493-503.

60 Badiou, Being and Event (London: Continuum, 2005), 175.

61 Ibid., 190

62 Ibid., 229.

63 Ibid., 512.

64 Ibid., 371.

65 Ibid., 525.

${ }^{66}$ Badiou, Logics of Worlds, pp. 321-324.

67 Badiou, Theoretical Writings (London: Continuum, 2003), 199.

68 Badiou, Being and Event, pp. 23-30. 
69 Agamben, The Kingdom and the Glory: For a Theological Genealogy of Economy and Government (Stanford: Stanford University Press, 2011), pp. 237-259. See also William Watkin, Agamben and Indifference: A Critical Overview (Lanham: Rowman and Littlefield, 2014).

70 Badiou, The Communist Hypothesis (London: Verso, 2010), pp. 229-259.

71 Badiou, Conditions, 174.

72 Ibid., 171.

73 Ibid., 174. 